\title{
STUDENTS' DIFFICULTIES IN USING PERSONAL PRONOUNS IN WRITING RECOUNT TEXT
}

\author{
Helty Sinaga', Herman ${ }^{2}$, Bertaria Sohnata Hutauruk ${ }^{3}$ \\ 1 Undegraduate student of Universitas HKBP Nommensen (UHN), Medan, Indonesia \\ 2,3Universitas HKBP Nommensen (UHN), Medan, Indonesia \\ heltysinaga1998@gmail.com¹, herman@uhn.ac.id², bertariahutauruk@uhn.ac.id³
}

Received: 05/08/2020, Accepted: 07/08/2020, DOI: 10.32923/sci.v5i1.1341

\begin{abstract}
This study is aimed to investigate the students' difficulties in using personal pronouns in writing recount text at grade eight of SMP Negeri 8 Pematangsiantar". In this research, the problem is as follows: "What are the students' difficulties in using personal pronouns in writing recount text at grade eight of SMP Negeri 8 Pematangsiantar?". The objective is to find out the students' difficulties in using personal pronouns at grade eight of SMP Negeri 8 Pematangsintar. To answer the problem above, the researcher intends to use the theories of: Collins (2014),Siahaan (2007), Derewinka (1990), William (2005), Frank (1972). The methodology used in this research is the Qualitative research. Subject this research is grade Eight of SMP Negeri 8 Pematangsiantar. The data collected by observation. After analyzing the data, the researchers found that there were three kinds of students' difficulties in using personal pronouns in writing text, namely: Personal pronoun as subject (34\%), personal pronouns as object (24\%), and personal pronoun as possessive adjective (42\%). It can be concluded that the students' at grade eight of SMP Negeri 8 Pematangsiantar still have difficulties in using personal pronouns when they write a recount text based on their experience. The researchers suggest the students' should memorize the kinds of personal pronouns so they can use it well.
\end{abstract}

\section{Keywords: Difficulties, Personal Pronoun, Recount Text, Writing.}

\section{Introduction}

Language is a system of communication used by particular country or community. According to Fernandez andHelen (2011:6) as cited in Pasaribu, Herman and Hutahaean (2020:12), language is primary communication system for human beings, but it isnot the only way to communicate, so language can be distinguished from communication ingeneral. Based on the explanation above it can be concluded that language is a communication tool that is always used by humans. Because of that language has an important role for human life, by using language, people can express their ideas, emotion, thought, and so on to others.

Many languages used in the world such as Mandarin, Japan, English, Spain, Indonesia and etc. But English is an international language that use in all of the country. So English is a global language that many people used it as their first or second language. In Indonesia, English a foreign language. Although in Indonesia English is not a second language, but the government considering English is important, then English made into one of the subjects included in the curriculum. English cover four language skills; listening, speaking, reading, and writing.

According to Sapkota (2012:70), "writing is an activity of putting down the graphic symbols which has a function to present a language in order to convey some meaning so that the reader can grasp the information which the writer has tried to convey". In addition, Brown (2001:336) states, "writing is a process of thinking". This idea is supported by Nunan (2003:88), which also explains that "writing is the process of thinking to invent ideas, thinking about how to express ideas into good writing, and arranging the ideas into statement and paragraph clearly". Based on the statements above, the researcher concludes that writing is a process to express ideas or thought in words and text form that give information for people. Writing is also the process of arranging word, letter, sentence and paragraphs, structures and some others related to one another. That's why writing is considerate to be the most difficult skills that learnt in English.

The statement is in line to Richard and Renandya's statement (2002:303) they stated that, "writing is the most difficult skill for foreign language learner to master". Writing is a complex activity because it needs many aspects to be mastered such as vocabulary, grammar, and ideas. Those aspect are still a problem that occurs in reality. Problem like that are also depicted in researcher's experience in teaching practice. There 
were many problems found in the students when writing a text such as student were not able to use personal pronouns in writing, did not know the kinds of personal pronouns, and still made mistakes in using that.

The problem in writing is not just in using personal pronouns. Other problems faced by the students in writings include poor vocabulary, misspelled words, punctuation, grammatical problem, mechanical problem and sentence structure problem.

For example:

Nina wants to buy a doll to his boyfriend, because he loves her very much.

After analyzing the example, the students still have difficulties in using personal pronouns in sentence. The example of sentence above is wrong.

The correct example is :

Nina wants to buy a doll to her boyfriend, because she loves him very much.

Based on the explanation above, the researcher is interested to conduct a research entitled "Students' Difficulties in Using Personal Pronouns in Writing Recount Text at Grade Eight of SMP Negeri 8 Pematangsiantar".

\subsection{Definition of Writing}

Writing is one of basic language skills that is important to be learned in learning language. According to Allen (2003:9), "Writing is an activity which can seriously damage your health. It can consume huge amount of time and energy, and it can lead to frustration, rage, and bitterness." In writing, the organization of ideas is very important. When we talk about writing, we often think about elements like word choice, grammar and content of evidence. The clear logical organization is one important part of effective writing. So it means that writing should communicate something clearly, precisely and unambiguously, so that the readers can comprehend the writer of what is being written about.

Writing is the skill of a writer to communicate information to a reader of group of readers (Siahaan, 2008). Consequently, we need practice to write paper or essay a lot for drilling our skill in writing because writing is a different from other skills with a good skill, we can create interesting scientific work. In other hand, we can prevent the reader from misunderstanding if our writing use correct grammar.

Writing is very difficult from other skills because we need full concentrate to choose interesting topic and write with correct grammar. This difficulty is not only generating and organizing idea, but also in translating these ideas into readable text. That is way writing becomes the last language skill to be taught after listening, speaking, and reading skill.(Rosa, 2014:79). It means that writing has different difficulty level with other skills because writing need systematic sequence of sentences and skill translate well. In practicing, teacher have to make interesting media to engage their students because writing have some method to become good paragraph. In a fact, students in Indonesia felt confuse to translate between Indonesia to English and contrarily. Thus, writing is a set of paragraphs that consists noun, verb, adjective, phrase, etc. If the components became one unit, they would be good paragraph and made the reader bring out in the story. Based on Rosa (2014:79), Writing is process of exploring the writer's thoughts to manifest the graphological and grammatical system of language by using visual medium in the form of sentences.

From definitions by experts, we can conclude if writing is a part of skill in English learning activities and has a different characteristic among them. Moreover, writing composed of sentences that have a important meaning for the reader. Besides, writing also need organizing idea to share the information for the reader. Not only organizing idea but also writing show graphological and grammatical system language it means that the writer has a characteristic to share their idea in writing. Therefore, the writer make the reader easy understanding the content from paragraph and the purpose of the text was made by the writer. Consequently, the writer should resemble their scientific work with correct grammar and systematic sentences. However, we should know the process of writing. In this way, we can make a good paragraph with sentences sequences systematically, Therefore, the process of writing would explained in next point.

\subsection{The Process of Writing}

Writing has five process to become good paragraph. Therefore, the writer should follow steps of writing that become provision in writing. The elements are prewriting, outlining, Drafting, revising, and editing.

\section{1) Prewriting}

Prewriting is a technique in writing that use general topic or the collecting idea from the writer. The purpose from this strategies are we can imagine what the topic that would be write and we can also make a 
draft from our idea. According to McLean(2012:381), Prewriting is the stage of the writing process during which you transfer your abstract thoughts into more concrete ideas in ink on paper. It means that, prewriting is a topic idea that would be basic to write information and it's still abstract. After that, the writer can organize their idea on the paper as a draft or outline. In prewriting also has four strategies that can help the writer. There are choosing topic, using experience and observation, reading, and free writing.

a) Choosing Topic

Choosing topic is a strategy when the writer decided what the theme that would be write. McLean (2012:381) stated that the first important step is for you to tell yourself why you are writing (to inform, to explain, or some other purpose) and for whom you are writing. It means that, the writer have to know the reason why he want to write. Then, they choose the topic before the writer began to write. Moreover, the writer can make a plan about the scientific work that would be made by the writer.

b) Using Experience and Observation

Using experience and observation can become the alternative way for the writer to begin their writing. Moreover, the writer can use their experience during their life as a unique topic and help them to more easy in writing. Besides, the purpose of observation is to guide the writer choose interesting topic based their experience that has been happened.

\section{c) Reading}

Reading is a strategy in prewriting where the writer search references to support their scientific work. Moreover, the purpose of reading in this strategy is to support their idea or topic that have been chosen by the writer. Therefore, reading can make the topic of writing has a progress to become systematic paragraph.

\section{d) Free Writing}

Free writing is a technique where the writer write anything based on they wanted and their mind. This technique can help worried feeling by the writer about correct grammar and mistake meaning.

\section{2) Outlining}

After prewriting technique has done, the writer have to make a outline before they began their scientific work. Moreover, outlining is a process where the writer to write keyword that would be object of scientific work. The purpose of the technique is helps the writer to write systematic paragraph and focus in a topic that have been chosen by the writer. Moreover, the writer just write the point of the topic.

\section{3) Drafting}

Drafting is a process where the writer completes their paragraph or essay with new idea. The purpose this strategy to help the reader easy understand the information. Besides, in drafting process the writer began first writing with introduction, body paragraph, and conclusion.

\section{4) Revising and Editing}

Revising and editing is important process in writing where the writer would be checked their scientific work. In this step, the writer read again the topic of scientific work and match with content of sentences that written by the writer. Besides, the writer try to edit their work if there are error mistake like grammar and revise to become correct grammar.

\subsection{Recount Text}

According to Rosyadi (2011), recount is a piece of text that retells past events, usually in the order in which they happened. The purpose of a recount text is to give the audience a description of what happened and when it happened. Recounts are used to relate experiences or retell events for the purpose of informing, entertaining or reflecting. Based on Knapp and Watkins (2005: 224), recount text basically it is written out to make a report about an experience of a series of related event. A recount is written out to inform an event or to entertain people.

Recount text is text function as for telling an incident in the past. Recount is to tell "what happened". A recount text has a social function. The purpose of a social function is to retell an event with a purpose to inform or entertain the readers. (Siahaan and Shinoda, 2008:9). Recount tells a series of event and evaluates their significance in some ways. It is also to give audience a descriptions of what occurred and when it occurred. The story recount has expressions of attitude and feeling, usually made by narrator about the events. 
A recount text has a social function. Recount tells what happened. The purpose of a social recount is to document a series of events and evaluate their significance in some way. It is also to give the audience a descriptions of what occurred and when it occurred. The purpose of recount is to tell a sequence of events so that it entertains. The recount has expressions of attitude and feeling, usually made by narrator about the events.

\subsection{Difficulties in Writing English}

Like all learning problems, difficulties in writing can be devastating to a student's education. Heaton (1975) stated that writing skill is complex and sometimes it is difficult to teach. Requiring mastery are not only of grammatical and rhetorical devices but also of conceptual and judgmental elements. As students' progress, they are increasingly expected to express what they know about many different subjects through writing. If a student fails to develop certain basic skills, he will be unable to write with the speed and fluency required to excel as these demands increase. Indeed, for a student's struggling with a writing problem, the writing process itself interferes with learning. Students faced with such difficult odds have trouble staying motivated.

The basic point that makes writing difficult is the use of language aspect or ability in written likes punctuation, spelling, grammatical, vocabulary and so on. According to Jordan (1997), writing is often confusing with the process of putting words down on paper in the same structure as an outline prepared with appropriate style and vocabulary the major ideas arranged in some often on the correction of mechanical and grammatical errors. Bryne(1988) divided the problems that make writing difficult into three categories. The first is Linguistic Difficulty. Linguistics aspect like grammar, vocabulary, language use and choice of sentence in writing must have fully monitoring. The second is Physiology Difficulty, which more focuses on the writer's difficulty because there aren't direct interaction and feedback from the reader when they are writing. This difficulty more focuses on difficulty in develop written material or content of composition. The third is cognitive difficulty. Writing has to be thought through formal instruction like spelling, punctuation, capitalization and paragraphing.

\subsection{Writing and Grammar}

Learning writing is fun. Students can write anything that they want. The students can have fling in their writing. Linse (2006:98) stated writing is multifaceted, it is only logical that it evokes different images. It means that every student can have different ideas in their writing because they have different experiences. Moreover, based on Sokolik (2003) in Linse (2006:98) writing is a combination of process and product.

The process is concerning about the act of collecting ideas and working with them until they are presented in manner. The concept that writing that is a process is very useful, Olson (2003) in Linse (2006:98). It can besay that the process of writing is important because the students should combine their imagination and sentences in the process. Writing is applying an idea or a concept which written that has a meaning or sense. Writing needs process-steps in producing a good quality of writing.

There are some processes in producing a good writing. Linse (2006:101)stated the process begins by thinking about what is going to be written and collecting ideas both formally and informally. The last step is publishing. The real definition of publish is writing the ideas in a piece of paper so that the writing can be shared with others. Writing is not only written some ideas in written language, but there are also some steps that followed to create a good writing.

Writing needs grammar. William (2005:2) stated that grammar is the formal study of the structure of a language and describes how words fit together in meaningful constructions. The process of writing needs grammar as the final process to organize the language structure and combine with other words to make sentences correctly. Grammar is about rules of language exploring structures. The rules are correct or incorrect, but are judge more on how well they are able to reflect actual standard English usage. (Alsagoff, 2008:2).

Moreover, learning grammar is very important. Alsagoff (2008:5) argues, pedagogical grammars often try to simplify thing to make the language system easier for learners to understand. In short, using grammar in writing is very .useful because the language can be easier to understand with the correct structure. Grammar has three schools of knowledge. They are traditional, formal, and functional grammar. Gerot and Wignell (1994:5) stated traditional grammar aims to describe the grammar of standard English by comparing it with Latin and it focuses on rules for producing correct sentences.

Formal grammar is about describing the structure of individual sentences. Moreover, Gerot and Wignell (1994:6) also argue that functional grammars view language as a resource for making meaning. These 
grammars attempt to describe language in actual use and so focus on texts and their contexts. Traditional and formal grammars discuss how the sentences are structured whereas functional grammar is about how the meaning of the texts is realized.

\section{Method of Research}

In this research, researchers used qualitative descriptive method. Thus, the researchers investigated about difficulties in using personal pronouns made by students in writing recount text. Creswell (2011:4) as cited in Pasaribu, Herman and Hutahaean (2020:15) stated that qualitative research is a research for exploring and understand the meaning individuals or groups a scribe to social or human problem. It means qualitative is a research design where the researcher presenting the data with using description. Moreover, the purpose of qualitative is to help the researcher found the solution of the phenomenon happened in society with doing investigation to the object research. According to Ritchie and Lewis (2003), "qualitative method is method that used to get information about social phenomena". Principally, descriptive qualitative research is used to reveal the condition of the phenomena as clearly as possible without any treatment. From explanation above we could conclude if the researcher who used qualitative research, they should be objective to give opinion in their research. Moreover, the researchers should be consistent to give opinion because the result of qualitative is static.

\subsection{Subject of Research}

The subject of this research is students' at grade eight of SMP Negeri 8 Pematangsiantar. There are nine classes at eight grade and 252 students. But, for this research the researcher only uses one class namely VIII- 8 with 28 students.

\subsection{Object of Research}

The object of this research is students' writing recount text about an experience which containing personal pronouns.

\subsection{Instrument of Data Collection}

A. Test

According to Ary, Jacobs, and Sorensen (2010:201), a test is a set of stimuli presented to an individual in order to elicit responses on the basis of which a numerical score can be assigned. The test is making recount text about an experience which containing personal pronouns.

\section{B. Validity}

According to Cohen, Manion, and Morinson (2005:105), validity is an important key to effective research. If a piece of research is invalid then it is worthless. The researcher use content validity. Content validity is used to compare content of the test to the domain being measured. Content validity just focused on how well the items represent the intended area

\section{Media}

There are some media that researcher using in this research;

a) Handphone, the researcher using handphone in this research to takes a picture as the research documentation.

b) The other documents as the instrument of the research are the paper test that collect during the research.

\subsection{Technique of Data Collection}

This research will be describing what the students' difficulties in using personal pronouns in writing recount text. Automatically, the researcher will give them a test of personal pronouns. Before giving a test, the researcher will give some materials like reviewing about recount text. It will start with what recount text were, what is generic structure were, language features of recount text. Hope, the students can understand the material after the researcher reviewed the materials. The researcher will come to the school in advance before giving the materials in order to ask some questions for an English teacher about the students. It can give some information, so the researcher can decide what kinds of a test which would be given to the students.

For giving the materials, the researcher will come to class without the teacher. The researcher reviewed all the materials of recount text. Starting with explaining what recount text are in order to give building knowledge for them. Then, the researcher mentioned what is generic structure of recount text. It can enrich the 
students' knowledge. Next, the researcher will explain the language features that consist in recount text but focus in using personal pronouns. Then, the researcher will give the real examples in using personal pronouns. For example: I go to school with my friends.

After giving the materials, the researcher will give the students a test. The test is writing a recount text. writing a recount text about an experience which containing personal pronouns. The last, the researchers analyzed the data.

\subsection{Technique of Data Analysis}

The data were analyzed in the following steps:

1) Reading the students' writing recount text.

2) Paying attention to the use of personal pronouns made by students.

3) Classifying personal pronouns made by students.

4) Checking the students' answer.

5) Giving the score.

6) Identifying the data based on the students' answer.

7) Looking for students' difficulties in personal pronouns based on the data.

8) Concluding the result whether the students have mastered in using personal pronouns or not based on writing recount text.

\subsection{Triangulation}

In qualitative research, the researcher will reveal the data as the real life of the subject. This qualitative research used some methodologies. To make the data valid, triangulation was employed. According to Creswell (2010) explained that, triangulation is the process of justifying evidence from different individuals, type of data, or methods of data collection. In this case, the aim of triangulation is to determine the truth about some social phenomenon, rather the purpose of triangulation is to increase one's understanding of whatever is being investigated. The researcher uses the theory of personal pronouns by Frank (1972:19) that show there are five types of personal pronouns.

\section{Result}

From the data has been analyzed in the previous point, the researcher found that the kind of students' difficulties in using personal pronoun in writing recount text at grade eight of SMP Negeri 8 Pematangsiantar in class VIII-8 covered Personal pronoun as subject, Personal pronoun as object, and Personal pronoun as possessive adjective.

The difficulties of personal pronoun as subject happened when students make a sentence that contain two subject, the students think that subject one and subject two can not stand with the same word. The difficulties of personal pronoun as object happened when students make the repetition of object in sentence. The students sometimes forget to put kinds of personal pronoun as object. The researcher assumed that the students often feel confuse to choose or to use the word to be the right object of pronoun. The difficulties of possessive adjective also happened because the students misplace kinds of possessive adjective and they do not know that possessive adjective are used to show possession or ownership of something, they are always located directly before the noun.

The dominant difficulties in using personal pronouns can we see on the table below

Table 1. Percentage kinds of difficulties

\begin{tabular}{ccc}
\hline Kind of Difficulties & Frequency & Percentage \\
\hline personal pronoun as subject & 21 & $34 \%$ \\
personal pronoun as object & 15 & $24 \%$ \\
personal pronoun as possessive adjective & 26 & $42 \%$ \\
\hline
\end{tabular}




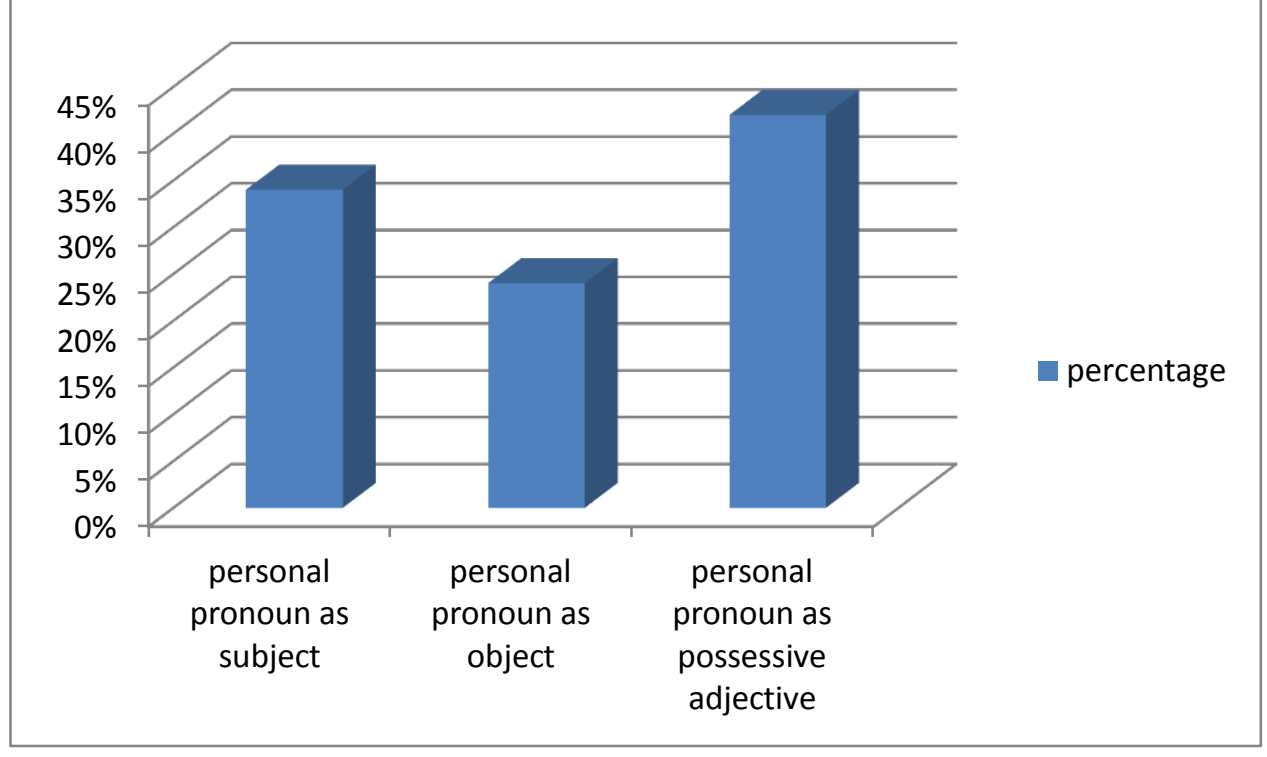

Chart 1. The percentage of students' difficulties

Table above shows that the dominant kinds of students' difficulties in using personal pronouns in writing recount text is personal pronoun as possessive adjective are $42 \%$, the second dominant is personal pronoun as subject are $34 \%$ and the third dominant is personal pronoun as object are $24 \%$.

\section{Discussion}

Based on the finding above, the researchers would like to discuss about the results found in this research to the previous research done before by Rina Reflia Nursi (2014) in her research entitled "The Students" Ability in Using Personal Pronouns in Narrative Paragraph at Second Year of SMA N 1 Duri". The research has reported that the students ability in using personal pronouns in narrative paragraph is good categorized (76,16\%), the researcher just took $15 \%$ of 319 students as sample. It was 48 students. Second, there are two factors that influence the students' ability in using personal pronouns in narrative paragraph, they are: internal factor and external factor. The similarities of both research is use the same method that is qualitative research, use the percentage to show the data and ask the students' to write a text for collecting the data. And the differences of both research is first researcher do not do the interview for student meanwhile the second researcher do the interview for students, the first researcher also conducting a research in Junior High School and the second researcher conduct the research in Senior High School.

\section{Conclusion}

Based on research finding and discussion of students in using and applying personal pronouns in writing recount text at grade eight of SMP Negeri 8 Pematangsiantar in academic year of 2019/2020, the researchers depicted that there are three difficulties in using personal pronouns in writing recount text. They are personal pronoun as subject, personal pronoun as object and personal pronoun as possessive adjective. From all data, the researchers conclude the dominant difficulties in using personal pronoun in writing recount text. The first dominant is personal pronoun as possessive adjective are $42 \%$, the second dominant is personal pronoun as subject are $34 \%$ and the third dominant is personal pronoun as object are $24 \%$. Then the researcher also can describes some conclusions from 28 stories that are written by the students at grade eight of SMP Negeri 8 Pematangsiantar,that is some of students at grade eight of SMP Negeri 8 Pematangsiantar do not know well how to write a paragraph into recount text. They still find some problems in making the grammatical sentence, problems in using tenses, and find some problems in using the appropriate words.

\section{References}

Ary, D., Jacobs, L. C., \& Sorensen, C. (2010). Introduction to Research in Education. Belmont, CA: Wadsworth, Cengage Learning.

Azar, B.S. (1989). Understanding and Using English Grammar. New Jersey: Prentice- Hall. 
Brown, H. D. (2001). Teaching by Principle: An Interactive Approach to Collins cited in Asma Abdul Aziz"s Journal. Learning Difficulties and Strategies at Higher Secondary School.(Journal of Policy Research, 1(2), 2014), 5.

Creswell, J.H. (2010). Educational Research Planning, Conducting and Evaluating Quantitative and Qualitative Research, 4th Edition, (Boston: Pearson Education, Inc., 2010, 259.

Creswell, J. W. (2014). Research Design: Qualitative, Quantitative, and Mixed MethodsApproaches. Fourth Edition. California: Sage, ISBN-978-1-4522-2610-1 (pbk.)

Frank, M. (1972). Modern English Exercise for Non-Native Speaker Part 1: Part of Speech. New Jersey: Prentice- Hall.

Gerot L and Wignell P. (1994). Making Sense of Functional Grammar. Sydney: Stabler.

Herman. (2014). An experiential Function on Students' Genre of Writing. Jakarta: Halaman Moeka.

Herman, Sibarani, J. K., and Pardede, H. (2020). The Effect of Jigsaw Technique in Reading Comprehension on

Recount Text. Cetta: Jurnal Ilmu Pendidikan. Jayapangus Press,ISSN 2615-0891 (E). Vol. 3 No. 1 (2020).

PP. 84-102

Knapp, P and Watkins, M. (2005). Genre Text, Grammar: Technologies forTeaching and Assessing Writing. Australia: University of New SouthWales Press Ltd.

Nunan, D. (2003). Practical English Language Teaching. New York: McGraw-Hill/Comemporary.

Pasaribu, B., Herman, and Hutahaean, D. T. (2020). Students' Difficulties in Translating Narrative Text From English Into Indonesia at Grade VIII of SMP Negeri 9 Pematangsiantar.Acitya: Journal of Teaching \& Education, 2(1), 13. Accessed from http://journals.umkt.ac.id/index.php/acitya/article/view/1311

Richard, J. C. and Renandya, W.A. (2002).Methodology in Language Teaching an Anthology of Current Practice, Cambridge University Press.

Ritchie, J., \& Lewis, J. (2003).Qualitative Research Practice-A Guide for Social Science Students and Researchers. London, Thousand Oaks, CA: Sage Publications Ltd.

Sapkota, A. (2012). Developing Students' Writing Skill through Peer and Teacher Correction: An Action Research.Journal of Nelta. 17:70-82. 